\title{
Price transmission along the Lithuanian pigmeat supply
} chain

\author{
Nelè Jurkènaitė ${ }^{1}$, Dimitrios Paparas ${ }^{2}$
}

\author{
1 - Lithuanian Institute of Agrarian Economics, Vilnius, Lithuania \\ 2 - Harper Adams University, Newport, Shropshire, the United Kingdom
}

\section{Keywords:}

Agriculture

Market

Pork

Price

Supply

\section{Article history:}

Received

12.05.2019

Received in revised

form 28.09.2019

Accepted

30.03.2020

\section{Corresponding} author:

Nelè Jurkènaitè

E-mail:

nele@laei.lt

DOI:

$10.24263 / 2304-$

974X-2020-9-1-20

\section{Abstract}

Introduction. The paper analyses structural changes of pig farming in Lithuania and explores price behaviour along the Lithuanian pigmeat supply chain.

Materials and methods. The conducted study uses annual indicators collected by Statistics Lithuania and weekly prices published by SE 'Agricultural Information and Rural Business Centre' (AIRBC). Methods of comparative analysis and graphical representation allow investigating the most important changes of the Lithuanian pig farming. Price behaviour is studied employing econometric tests showing the characteristics of the analysed pigmeat price series and different aspects of price relations in the short- and long-term perspective.

Results and discussion. The share of small-sized farms is decreasing in the structure of pig farms, while farmer and family farms have lost their key role in pig farming, in particular between 2004 and 2018. In 2004, the share of pigs that were grown on farmer and family farms accounted for $56.7 \%$ of the population, while in 2018 a drop to a critically low $24.9 \%$ level was demonstrated. During the period from 2007 to 2016, the decrease in the share of farms with 10 animals and more was from 3.1 to $2.5 \%$, while the share of farms with 3-9 pigs increased from 34.7 to $47.9 \%$. This development direction of pig farming was caused by multiple factors, including the change of the business environment after 2004, the transformation of agricultural support model and aftermaths of price hikes, the impact of the governmental intervention due to the integration into the Eurozone, as well as animal health issues.

Price transmission analysis demonstrates that the pork market had faced several critical shocks that had an impact on price behaviour and stakeholders' welfare. However, the Johansen cointegration tests show that the most significant structural break was in 2013. The Granger causality test confirms that the price setting direction runs from retail to farm, while, in the long run, the hypothesis of the asymmetric behaviour is not supported. According to the results of Vector Error Correction Model, pigmeat prices return to the described equilibrium with a speed $3.6 \%$ for the analysed period.

Conclusions. The study confirms the dramatic change of the Lithuanian pig farming sector. A test for price symmetry does not show market efficiency problems, but in the short-run one-way causality is present. 


\section{Introduction}

According to OECD-FAO agricultural outlook [22], in Europe, pork meat consumption per capita was the highest among all meat varieties since 1990. However, on a global scale this trend had changed in 2007 and poultry became the most popular globally consumed meat variety, while pork meat was the second most important meat in the world.

Thus, the topic of pigmeat price transmission attracted a huge attention from academic society around the world. The most recent research covers studies of domestic supply chains in Australia [15], Czech Republic [7, 25], China [8, 10, 28], Denmark [19], Finland [20], France [19], Germany [19, 29], Hungary [3], Ireland [19], Italy [6], the Netherlands [19], Poland [18], Slovenia [5], Switzerland [1], the United Kingdom [19, 23], the USA [13, 21], and etc. Studies investigate different aspects of pork market efficiency and therefore apply various sets of econometric techniques.

For example, $[1,3,4,6,8,10,13,15,19,20,21,25]$ focus on issues of asymmetric price behaviour along the pork supply chain employing various research methods allowing to investigate both short- and long-term relationships among the supply chain. Some studies have a particular interest in impact of different factors [8] and the regime-dependent prices behaviour [13]. [2, 3, 4, 5, 6, 10, 18, 23, 28] describe the relations between prices on different level of the supply chain. According to research results, academics find both symmetric and asymmetric behaviour of prices along the domestic supply chain, research findings do not allow making a generalized conclusion on the leading price setting stakeholder or describe price relations and equilibrium adjustment speeds as similar. The findings of the aforementioned studies imply that price behaviour and relevant market efficiency challenges depend on the country. It should be noted that even the common market of the EU is rather a set of sufficiently diverse supply chains reflexing market peculiarities of the countries.

This fact makes the study of the Lithuanian pigmeat supply chain an interesting topic, because the previous research on price transmission in this country is scarce due to data availability. Based on the previous research, this paper selects a framework of econometric tests that show multiple aspects of price behaviour along the supply chain. It is important to note that since Lithuania had joined the European Union (EU), the domestic pig farming sector got through the serious structural transformations. The overall population of pigs reduced, while the dominant share of animals on farmer and family farms was replaced by the leading role of agricultural companies and enterprises. The aforementioned changes could have a significant impact on price behaviour along the pigmeat supply chain and influence the welfare of stakeholders along the pigmeat supply chain.

The paper is aiming to analyse the structural changes of pig farming in Lithuania and explore the price behaviour along the Lithuanian pigmeat supply chain. The study identifies the main factors that have had an impact on the pork sector evolution and focuses on prices as an important component that could have an impact on pig farming development trends in Lithuania.

\section{Materials and methods}

\section{Materials}

The study relies on main annual indicators of pig farming collected by Statistics Lithuania and weekly upstream and downstream prices of pigmeat published by AIRBC. The upstream level is measured by the average purchase price of pigs (confirmation class E) 
collected from the Lithuanian enterprises on weekly basis. The downstream price level is measured by the average retail price of ham without bones calculated from retail prices of the main network supermarkets in Lithuania. The price transmission study is carried out for the period 2010-2017.

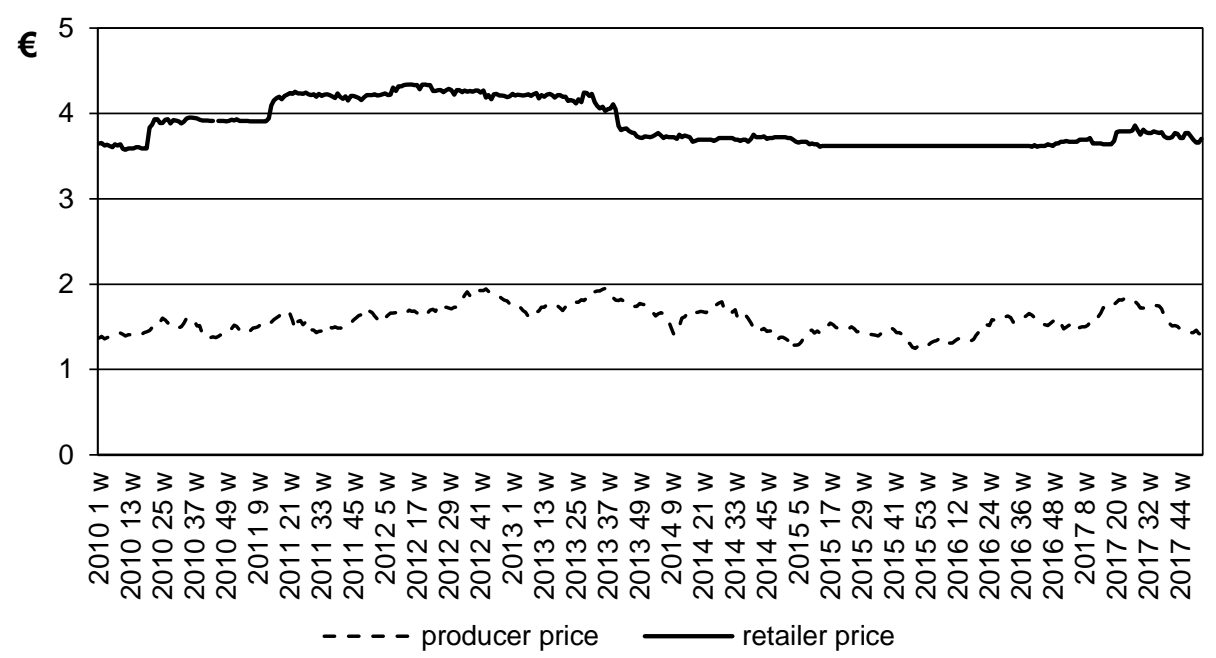

Figure 1. Pigmeat prices on producer and retailer levels

Source: AIRBC, own calculations.

According to Figure 1, the gap between upstream and downstream prices is changing during the analysed period. Downstream prices are less volatile than the prices on upstream level. Starting from 2014, an interesting behaviour of the price on downstream level is observed. Retail price stabilizes for the long period and does not respond to price fluctuations on producer level, while starting from 2017 it becomes more dynamic. This situation could be a result of couple inter-related factors. For example, the influence of the legislation controlling price hikes before and after the entrance to the Eurozone, as well as the reaction of retailers to the threat of African swine fever on domestic market and the change of the situation after the Russian ban.

The investigated Lithuanian pigmeat supply chain demonstrates a higher price volatility on producer level, while retail prices are more stable. In fact, the analysed case is similar to the functioning of pigmeat supply chains in Czech Republic [25] and Poland [18], while the opposite price development trend is evidenced in Slovenia where retail prices demonstrate higher volatility than prices on farm [5]. However, some studies provide examples of quite similar volatility on both levels of the country, for example, price development in China [10], Italy [6], and Finland [20]. Hence, the behaviour of prices on different supply chain levels of the same commodity depends on the country.

\section{Methods}

At the first stage the study applies methods of comparative analysis and graphical representation to investigate changes on the Lithuanian pig farms. The findings are drawn on the basis of the analysis of main indicators published by Statistics Lithuania. 
At the second stage the price transmission along the pigmeat supply chain is explored. Firstly, the nature of data is investigated in order to characterize price series as stationary or non-stationary. For this purpose, Augmented Dickey Fuller (ADF) [9] test is run. This test allows to judge about reliability and validity of the data [27]. Additionally, we deployed the Bai-Perron test [2] in order to take into account potential structural breaks. It assists in avoiding the rejection of the null hypothesis $\left(H_{0}\right)$ [24] when the results could be meaningful.

At the third step the Johansen co-integration test $[16,17]$ is carried out to answer the question if there is a co-integrating vector or vectors between downstream and upstream pigmeat prices. This step reveals if prices on different levels of the pigmeat supply chain repeat the movements related to price hikes and reductions in the long run. The absence of the co-integrating vector alerts about possible problems in price transmission resulting in market inefficiency issues.

At the fourth step the Granger causality test [14] is carried out. The results of this test allow to identify the direction of price running causality in the short-term perspective. The efficient market could be characterised by the two-way causality, while in case of price setting leadership on downstream or upstream level the welfare of farms or consumers could be violated.

At the fifth step the relations between upstream and downstream prices are described by vector error correction model (VECM). Characteristics and the application issues of this model are described in [30].

Finally, the threshold autoregressive (TAR) model $[11,12]$ is deployed. The initial step tests the $H_{0}$ that there is no cointegration between prices in the long run relationship. Next, the $H_{0}$ of symmetric adjustment mechanism between the farm and retail prices in the longrun equilibrium is investigated.

\section{Results and discussion}

\section{Structural changes of pig farming in Lithuania}

Over the last decades, the structure of the pig population on Lithuanian farms overcame a significant transformation. According to Statistics Lithuania, when Lithuania entered the EU in 2004, the share of pigs that were grown on farmer and family farms accounted for $56.67 \%$ of the population, while in 2018 a drop to a critically low $24.93 \%$ level was demonstrated. For the investigated period 2010-2018, the gradual increase of the share of animals at agricultural companies and enterprises and the corresponding changes in pig farming structure are demonstrated in Figure 2.

Another important characteristic is the structure of pig farming by herd size. The share of pigs on farms that had 1-2 pigs decreased very sharply from $10.22 \%$ in 2007 to $4.23 \%$ in 2016 [33]. At the same time, the share of pigs on farms with the herd size from 3 to 9 pigs dropped from $14.01 \%$ to $10.09 \%$. The share of pigs on farms with 10 pigs and more increased from $75.77 \%$ to $85.68 \%$. Furthermore, the corresponding decrease in the share of farms with 10 animals and more was from $3.06 \%$ to $2.51 \%$, while the share of farms with $3-9$ pigs increased from $34.74 \%$ to $47.93 \%$ during the period from 2007 to 2016 [33]. 


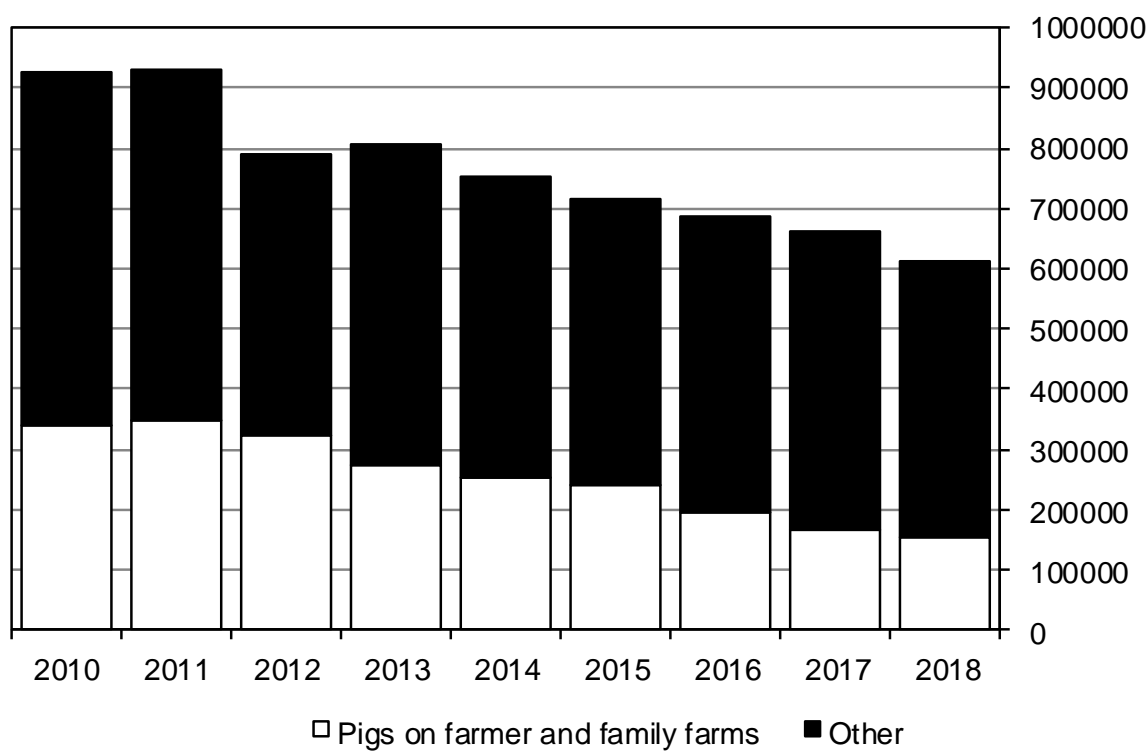

Figure 2. Structure of pig population by farm type in Lithuania for the period 2010-2018 Source: Statistics Lithuania [32].

Main indicators of supply balance sheets for pigmeat, thousand tonnes

Table 1

\begin{tabular}{|l|c|c|c|c|c|c|c|c|c|c|}
\hline & $\mathbf{2 0 1 0}$ & $\mathbf{2 0 1 1}$ & $\mathbf{2 0 1 2}$ & $\mathbf{2 0 1 3}$ & $\mathbf{2 0 1 4}$ & $\mathbf{2 0 1 5}$ & $\mathbf{2 0 1 6}$ & $\mathbf{2 0 1 7}$ & $\mathbf{2 0 1 8}$ & $\begin{array}{c}\text { Change } \\
(\mathbf{2 0 1 0}= \\
\mathbf{1 0 0 \%})\end{array}$ \\
\hline Produced & 73.3 & 74.9 & 79.4 & 86.9 & 84.9 & 84.3 & 74.0 & 71.5 & 72.0 & 98.2 \\
\hline Import & 78.5 & 83.2 & 85.4 & 90.6 & 84.1 & 91.8 & 83.8 & 89.0 & 92.1 & 117.3 \\
\hline Export & 15.3 & 23.2 & 27.6 & 35.7 & 22.3 & 27.6 & 17.0 & 19.7 & 23.3 & 152.3 \\
\hline $\begin{array}{l}\text { Total domestic } \\
\text { uses }\end{array}$ & 136.9 & 136.7 & 135.4 & 141.9 & 147.0 & 147.6 & 141.3 & 141.0 & 140.7 & 102.8 \\
\hline
\end{tabular}

Source: Statistics Lithuania [34], own calculations.

During the period 2010-2018, domestic production was growing until 2013, later, the Russian ban and African swine fever had an impact on the produced amounts of pigmeat and foreign trade. In 2018, both import and export of meat products (estimated in meat equivalent) increased, as compared to the year 2010. Total domestic uses also showed a sign of the moderate increase and statistics reacted to embargo and animal health problems (Table 1).

Hence, the current situation of the Lithuanian pig farming was determined by multiple factors inside and beyond pork sector. A crucial aspect was the change of the farming environment after the integration into the EU in 2004. Representatives of pig farming quickly 
realized that they could not compete with the leading pigmeat producing countries that were equipped with modern material facilities allowing to offer their product at a better price. The first years of the competition within the common market started from the clear understanding of two serious problems. First, there was a need to invest in modernisation of farms that produced pigmeat. Second, a change of traditional breeds of pigs to the new breeds, preferred by European consumers, was compulsory. However, the national agricultural support model did not spend a decent attention to this situation.

The introduction of the Common Agricultural Policy determined the establishment of the novel support model and gave another signal for the development of the national agriculture creating more favourable conditions for crop production. Global price hikes for agricultural commodities in 2007-2008 and 2010-2011 contributed to the growth of pig farming costs bolstering pig feeds. Direct payments and the growth of crop prices made crop production a more attractive farming niche.

In 2015, Lithuania became a member of the Eurozone and farmers faced a new dilemma. On the one hand, the prices for the related services were rising, on the other hand, the competition on the EU market did not allow to follow the general price development direction. Hence, for smaller farmers, the choice between the generously supported crop production and unprofitable pig farming became more obvious. The exit of small farms from pig farming often resulted in land rent and its further use for crop production on larger farms.

Another important aspect that contributed to the structural changes in pig farming was animal health. The outbreaks of classical swine fever in 2009 and 2011 had a significant impact on export restrictions of live pigs and the transformation of the foreign trade structure. At that time, the Russian Federation was the main trading partner for the Lithuanian pork sector; however, the outbreak of the classical swine fever in 2011 had stopped the export of live pigs until the second half of 2013. Hence, this situation encouraged farmers to look for new markets and switch from export of live animals to pigmeat products.

The subsequent opening of the Russian market was short, because in January 2014 the first outbreak of African swine fever was confirmed in Lithuania. This outbreak led to the confusion and the disturbance of foreign trade. The strength of the common market became the weakness as the European Commission could not quickly respond to a new challenge and propose the zoning, while a free cross-border movement within the EU became a threat. Later, the Russian market was closed due to import ban on EU agricultural commodities.

Nevertheless, the impressive geographical spread of African swine fever virus in wild nature and on Lithuanian pig farms was reported until 2018, while only in 2019 the figures started to fall down. As a comparison, according to statistics of the State Food and Veterinary Service [31], 1,446 spots in a wild nature and 3,098 infected wild boars were found in 2018, while by November $26^{\text {th }}, 2019$ only 430 infected places and 644 wild boars were documented.

The aforementioned disease led to the polarization of pig farming society in Lithuania, because a huge number of small farms was represented as a serious threat for commercial farms. The detection of virus on a small farm resulted in an export ban for larger commercial farms belonging to the same zone. It was argued that the spread of this virus in pig farming was rapid in countries that had a significant share of small farms [26]. The vulnerability of small farms was widely recognized due to the careless implementation of biosafety measures on those farms. However, the proposals to slaughter pigs and prohibit pig farming on small farms did not achieve enough support in Lithuanian agriculture.

Finally, a political decision to keep a diverse farming structure was made. On the one hand, the larger farms were proposed to get funding for farm modernization and the improvement of biosafety measures. Small and medium farms with less than 100 pigs, located in districts with African swine fever spots, were offered two types of the 
compensatory support from autumn 2018. The first type of the support assisted in improvement of biosafety measures on farms, while the second measure compensated a switch from pig farming to other livestock farming activities.

\section{Pigmeat vertical price transmission in Lithuania}

ADF test shows that pigmeat raw prices on downstream and upstream levels are not stationary, because the absolute value of ADF test statistic is lower than critical values (Table 2 ). However, pigmeat prices at both levels of the supply chain become stationary in first difference and it could be concluded that pigmeat prices are integrated of order one.

Results of unit root test for pigmeat prices

Table 2

\begin{tabular}{|c|c|c|c|c|c|c|c|c|c|}
\hline \multirow{2}{*}{\multicolumn{2}{|c|}{\begin{tabular}{c}
\multicolumn{1}{c}{ Ho: has } \\
a unit root \\
\multicolumn{2}{|l}{ Level } \\
\end{tabular}}} & \multicolumn{2}{|c|}{ lproducer } & \multicolumn{2}{|c|}{ D(lproducer) } & \multicolumn{2}{|c|}{ Iretailer } & \multicolumn{2}{|c|}{ D(lretailer) } \\
\hline & & $t$-stat & Prob. & $t$-stat & Prob. & $t$-stat & Prob. & $t$-stat & Prob. \\
\hline \multicolumn{2}{|c|}{ ADF test statistic } & -2.166 & 0.219 & -16.681 & 0.000 & -1.239 & 0.659 & -20.199 & 0.000 \\
\hline \multirow{3}{*}{$\begin{array}{l}\text { Test } \\
\text { critical } \\
\text { values: }\end{array}$} & $1 \%$ & -3.446 & & -3.446 & & -3.446 & & -3.446 & \\
\hline & $5 \%$ & -2.868 & & -2.868 & & -2.868 & & -2.868 & \\
\hline & $10 \%$ & -2.570 & & -2.570 & & -2.570 & & -2.570 & \\
\hline \multicolumn{4}{|c|}{ Lag Length: 1 (SIC, maxlag=17) } & \multicolumn{6}{|c|}{ Lag Length: 0 (SIC, maxlag=17) } \\
\hline
\end{tabular}

Source: own calculations.

According to the previous studies, the similar price behaviour is documented in studies on price series in Switzerland [1], Czech Republic [25], China [10], the United Kingdom [23]. Nevertheless, some studies evidence that data stationarity issues depend on supply chain level and pigmeat product, for example, case studies of Polish [18], Slovenian [5], and Czech [7] supply chains. It is not often the case that price series confirm an assumption of data stationarity, for instance the USA case study [21].

The Johansen co-integration test does not indicate the co-integrating equation and states that in the long run pigmeat prices do not move together. The results show that market faces efficiency problems, however, in some cases the explanation of such problems could be structural breaks that allow to find co-movements between breakpoints.

It should be noted that some researchers identify structural breaks and split price series analysis into sub-periods [5, 10] or integrate structural breaks into research $[4,23]$. The majority of the cases justifies the presence of such breaks in price series by crises [10, 19], animal diseases [1, 5, 23], governmental interventions [5], and other factors.

Thus, Bai-Perron test is run to investigate pigmeat prices for the presence of structural breaks. Bai-Perron test applies the break specification method ' $L+1$ vs $L$ sequentially determined breaks' and identifies five breaks for the investigated period: 1) 4/01/2011, 2) $7 / 27 / 2012$, 3) $10 / 04 / 2013$, 4) $2 / 20 / 2015$, 5) 10/21/2016. During the period 2010-2017, the Lithuanian pigmeat supply chain faced shocks of various origins, i.e. the change of the business environment, entrance to the Eurozone, price hikes, swine fever outbreaks, and the change of foreign trade partners as well as main trading commodities. The aforementioned factors influenced the price development and the efficiency of the Lithuanian pork market and contributed to the rise of the identified structural breaks. 
Further, the Johansen co-integration tests show that the most significant structural break was in 2013 and the inclusion of this dummy into the estimation process allows to receive meaningful results.

The Johansen test allows rejecting hypothesis that pigmeat prices on both levels are not co-integrated in the long-term perspective (Table 3). However, the hypothesis of one or two co-integrated equations cannot be rejected. Thus, the conclusion could be drawn that prices along the pigmeat supply chain are co-integrated.

Summarising the previous findings, it could be concluded that studies apply specific tests for the co-integration or the co-integration becomes an initial step of tests for symmetric price behaviour. The absence of the co-integration in Swiss pork sector is found by [1] applying the Engle-Granger test, however, tests for asymmetry finds the evidence of the co-integration. One co-integrated equation is found in the United Kingdom [23], or couple co-integrating vectors for the investigated period in China [10], while in case of Slovenia the split of time series into sub-periods allowed to find only one co-integrating equation instead of two [5]. Thereby, the situation on the Lithuanian market is not unique, and previous research shows quite different situation for the countries.

Table 3

Results of the Johansen co-integration test with linear deterministic trend and break in 2013 for pigmeat prices

\begin{tabular}{|l|c|c|c|c|}
\hline \multirow{2}{*}{\multicolumn{1}{|c|}{$\boldsymbol{H}_{\boldsymbol{0}}$ : }} & Eigenvalue & Statistic & $\begin{array}{c}\text { Critical Value } \\
(\mathbf{0 . 0 5})\end{array}$ & Prob. \\
\cline { 2 - 5 } & \multicolumn{4}{|c|}{ Trace test } \\
\hline No CEs* & 0.059 & 35.950 & 29.797 & 0.009 \\
\hline At most 1 CE & 0.022 & 11.445 & 15.495 & 0.186 \\
\hline At most 2 CEs & 0.006 & 2.545 & 3.841 & 0.111 \\
\hline & \multicolumn{4}{|c|}{ Maximum Eigenvalue test } \\
\hline No CEs* & 0.059 & 24.506 & 21.132 & 0.016 \\
\hline At most 1 CE & 0.022 & 8.900 & 14.265 & 0.295 \\
\hline At most 2 CEs & 0.006 & 2.545 & 3.841 & 0.111 \\
\hline
\end{tabular}

* rejects the null hypothesis at the 0.05 level. Lags interval (in first differences): 1 to 4.

Source: own calculations.

The next step explores if prices on different levels help to explain price behaviour on the opposite supply chain level in the short run. Table 4 introduces results of the Granger causality test for 2 lags. According to estimated values, the Lithuanian pigmeat market demonstrates features of one-way causality that runs from retailer to producer.

Results of the Granger causality test for pigmeat prices

Table 4

\begin{tabular}{|l|c|c|}
\hline \multicolumn{1}{|c|}{$\boldsymbol{H}_{\mathbf{0}} \mathbf{P}$} & $\boldsymbol{F}$-Statistic & Prob. \\
\hline 'Lproducer' does not Granger Cause 'Iretailer' & 0.179 & 0.67 \\
\hline 'Lretailer' does not Granger Cause 'lproducer' & 3.673 & 0.05 \\
\hline
\end{tabular}

Source: own calculations. 
It should be noted that the previous research also found evidences of one-way causality, however, the direction often runs from farm to retail level $[4,13,21]$ and corresponds to the price determination theory arguing that the causality should run from upstream to downstream sectors.

The VECM is assisting in describing the Lithuanian pigmeat market. The estimated VECM includes a structural break in 2013 as an addition parameter (Table 5). The estimated error correction term (ECT) shows that after shocks pigmeat prices return to the described equilibrium with a speed $3.6 \%$ for the analysed period.

\section{Estimation of VECM for pigmeat prices with break in 2013}

Table 5

\begin{tabular}{|l|r|}
\hline \multicolumn{2}{|c|}{ Co-integrating equation for Lithuanian case } \\
\hline lretailer(-1) & 1.000 \\
\hline lproducer(-1) & -0.222 \\
& $(0.099)$ \\
& {$[-2.242]$} \\
\hline D2013(-1) & 0.125 \\
& $(0.021)$ \\
\hline C & {$[6.041]$} \\
\hline Error Correction: & -1.331 \\
\hline ECT & D(lretailer) \\
& -0.0357 \\
& $(0.0084)$ \\
& {$[-4.279]$} \\
\hline
\end{tabular}

Source: Own calculations.

The main results of TAR model with constant and structural break for 2 lags are provided in Table 6. The selected threshold value is zero. The comparison of $F$-joint (6.45) with the critical value 5.81 allows rejecting the $H_{0}$ of 'no co-integration' and accepting the alternative that the series are co-integrated. Moreover, the $H_{0}$ of the symmetric price behaviour is not rejected, because $F$-equal $(0.53)$ is lower than the critical value (2.88). This means that increases and decreases of the prices are transmitted from the retailer to the producer - in the long run - with the same intensity.

Results of TAR with break in 2013 for pigmeat prices

Table 6

\begin{tabular}{|l|c|c|}
\hline \multicolumn{1}{|c|}{ Variable } & Coefficient & Std. Error \\
\hline Above Threshold & -0.040 & 0.0180 \\
\hline Below Threshold & -0.060 & 0.021 \\
\hline Differenced Residuals $(t-1)$ & 0.040 & 0.050 \\
\hline Differenced Residuals $(t-2)$ & 0.039 & 0.050 \\
\hline$F$-equal: & 0.537 & $(2.882)^{*}$ \\
\hline$T$-max value: & -2.199 & $(-2.094)^{*}$ \\
\hline$F$-joint (Phi): & 6.445 & $(5.811)^{*}$ \\
\hline
\end{tabular}

Source: own calculations. 
It is true to note that different tests for presence of asymmetry is one of the most often investigated issues. Academic studies show that different countries demonstrate both symmetric $[3,15]$ and asymmetric $[1,8,13,18,25]$ price behaviour or combine both types in a longer period [10] or in a long- and short-term perspectives [4], as well as on different levels of supply chain [21].

\section{Conclusion}

Over the period from 2010 to 2018, significant structural changes in the Lithuanian pig farming took place. The overall population of pigs had decreased, while the dominant role of agricultural companies and enterprises in pig production was growing. Small farms were disappearing from Lithuanian pig farming, because farmers exited pig farming or switched to other farming types, while the role of medium-sized pig farms in the country was not important in terms of production.

Other important factors, contributing to structural changes and demotivating to run medium-sized farms, were the growth of farming costs, animal diseases, and disturbances of foreign trade. The current negative trends could be changed introducing specific support measures targeting at fostering a specific pig farming structure.

The empirical research on price transmission along the Lithuanian pigmeat supply chain demonstrates that the pigmeat market experienced several critical shocks over the investigated period. Those shocks had different nature (governmental intervention, animal health issues, global price hikes) and made an impact on price behaviour and co-movements. Tests suggest that in the short-run the leading price setter is retailer. This result challenge for the investigation of farmers welfare issues.

In the long-term perspective, prices are transmitted from the retailer to the producer with the same intensity and do not demonstrate asymmetric behaviour. Asymmetry was not found within the investigated market for the period studied and this fact suggests that policies in place were working effectively during the analysed period. Hence, it should be noted that introduction of additional details (for example, more stakeholders along the supply chain or investigation of specific periods) could enrich the knowledge about the functioning of the Lithuanian market.

\section{References}

1. Abdulai, A. (2002), Using Threshold Cointegration to Estimate Asymmetric Price Transmission in the Swiss Pork Market, Applied Economics, 34(6), pp. 679-687.

2. Bai J., Perron pp. (1998), Estimating and Testing Linear Models with Multiple Structural Changes, Econometrica, 66(1), pp. 47-78.

3. Bakucs L.Z., Fertõ I. (2005), Marketing margins and price transmission on the Hungarian pork meat market, Agribusiness, 21(2), pp. 273-286.

4. Bakucs L.Z., Fertõ I. (2006), Marketing and pricing dynamics in the presence of structural breaks - the Hungarian pork market, 98th Seminar, June 29-July 2, 2006, Chania, Crete, Greece, European Association of Agricultural Economists, available at: https://www.researchgate.net/publication/23510115_Marketing_and_Pricing_Dynami cs_in_the_Presence_of_Structural_Breaks_The_Hungarian_Pork_Market.

5. Bojnec Š., Peter G. (2005), Vertical market integration and competition: the meat sector in Slovenia, Agricultural and Food Science, 14(2005), ppp. 236-249. 
6. Capitanio F., Adinolfi F., Goodwin B.K., Rivieccio G. (2019), A copula-based approach to investigate vertical shock price transmission in the Italian hog market, New Medit, 1(2019), pp. 1-14.

7. Čechura L., Šobrová L. (2008), The price transmission in pork meat agri-food chain, Agric. Econ. - Czech, 54(2), pp. 77-84

8. Dai J., Li X., Wang X. (2017), Food scares and asymmetric price transmission: the case of the pork market in China, Studies in Agricultural Economics, 119(2017), pp. 98-106.

9. Dickey D.A., Fuller W.A. (1979), Distribution of the estimators for autoregressive time series with a unit root, Journal of the American Statistical Association, 74(366), pp. 427-431.

10. Dong X., Brown C., Waldron S., Zhang J. (2018), Asymmetric price transmission in the Chinese pork and pig market, British Food Journal, 120(1), pp. 120-132.

11. Enders, W., \& Siklos, P.L. (2001). Cointegration and Threshold Adjustment. Journal of Business \& Economic Statistics, 19(2), 166-176.

12. Enders, W., \& Granger, C.W.J. (1998). Unit-Root Tests and Asymmetric Adjustment with an Example Using the Term Structure of Interest Rates. Journal of Business \& Economic Statistics, 16(3), 304-311.

13. Goodwin B. K., Harper D. C. (2000), Price Transmission, Threshold Behaviour, and Asymmetric Adjustment in the U.S. Pork Sector, Journal of Agricultural and Applied Economics, 32(3), pp. 543-553.

14. Granger C.W.J. (1969), Investigating causal relations by econometric models and crossspectral methods, Econometrica, 37(3), pp. 424-438.

15. Griffith G.R., Piggott N.E. (1994), Asymmetry in beef, lamb and pork farm-retail price transmission in Australia, Agricultural Economics, 10(1994), pp. 307-316.

16. Johansen S. (1991), Estimation and hypothesis testing of cointegration vectors in Gaussian vector autoregressive models, Econometrica, 59(6), pp. 1551-1580.

17. Johansen S. (1995), Likelihood-Based Inference in Cointegrated Vector Autoregressive Models, Oxford University Press Inc., New York.

18. Kufel-Gajda J., Figiel S., Krawczak M. (2017), Struktury rynkowe a transmisja cen w tańcuchach rolno-żywnościowych, Instytut Ekonomiki Rolnictwa $i$ Gospodarki Żywnościowe - Państwowy Instytut Badawczy, Warszawa.

19. London Economics. (2004), Investigation of the determinants of farm-retail price spreads: final report to DEFRA, London Economics.

20. Luoma A., Luoto J., Taipale M. (2004), Threshold Cointegration and Asymmetric Price Transmission in Finnish Beef and Pork Markets, Pellervo Economic Research Institute Working Papers, 70, Pellervo Economic Research Institute, Helsinki, pp. 1-31.

21. Miller D.J., Hayenga M.L. (2001), Price Cycles and Asymmetric Price Transmission in the U.S. Pork Market, Amer. J. Agr. Econ., 83(3), pp. 551-562.

22. OECD/FAO. (2019), OECD-FAO Agricultural Outlook 2019-2028, OECD Publishing, Paris/Food and Agriculture Organization of the United Nations, Rome.

23. Paparas D., Pickering T., Tremma O., de Aguiar, L.K. (2018). Is there a significant change in the price transmission between producer and retail prices within the British Pork industry?, Turkish Economic Review, 5(2): 174-190.

24. Rose H., Paparas D., Tremma O., de Aguiar L.K. (2019), Price transmission: the case of the UK and the USA broiler markets, Int. J. Agricultural Resources, Governance and Ecology, 15(4): 281-306.

25. Rudinskaya T. (2019), Asymmetric price transmission analysis in the Czech pork market, Journal of Central European Agriculture, 20(3), 986-994. 
26. Schulz K., Conraths F.J., Blome S., Staubach C., Sauter-Louis C. (2019), African Swine Fever: Fast and Furious or Slow and Steady?, Viruses, 11(866), pp. 1-16.

27. Stubley D. J, Paparas D, Tremma O, Aguiar, L. (2018), An Investigation into the Price Transmission between producers and retailers within the UK milk market. Advances in Business-Related Scientific Research Journal, 9 (1): 14-43.

28. Zhou D., Koemle D. (2015), Price transmission in hog and feed markets of China, Journal of Integrative Agriculture, 14(6), pp. 1122-1129.

29. Von Cramon-Taubadel S. (1998), Estimating asymmetric price transmission with the error correction representation: An application to the German pork market, European Review of Agricultural Economics, 25(1), pp. 1-18.

30. Von Cramon-Taubadel S. (2017), The analysis of market integration and price transmission - results and implications in an African context, Agrekon, 56, pp. 83-96.

31. (2019), AKM atveju statistika, available at: https://vmvt.lt/gyvunu-sveikata-irgerove/gyvunu-sveikata/gyvunu-ligos/afrikinis-kiauliu-maras/statistika.

32. (2019), Agriculture. Animal production, available at: https://osp.stat.gov.lt/statistiniurodikliu-analize\#/.

33. (2019), Farm structure. Farm animals, available at: https://osp.stat.gov.lt/statistiniurodikliu-analize\#/.

34. (2019), Supply balance sheets for agricultural products. Supply balance sheets for agricultural products for the crop year, available at: https://osp.stat.gov.lt/statistiniurodikliu-analize\#/. 